\title{
Olives: Origins and Development
}

\section{Charlene Murphy}

Institute of Archaeology, University College London, London, UK

\section{Basic Species Information}

The olive (Olea europea L.) tree is a subtropical evergreen plant that was indigenous to the Mediterranean Basin, confined by its intolerance of frost. It has adapted to long summer droughts and a semiarid temperate climate, well-drained soils, moderate-to-low pH (below 8.5), and mild soil salinity (Terral et al. 2004: 64; Doveri \& Baldoni 2007: 254-5). The genus Olea, belonging to the family Oleaceae, currently consists of more than 20 species found in tropical and subtropical areas over five continents. Recent revisions of the taxonomy surrounding $O$. europea suggest that this species should be divided into six subspecies based on morphology and geographical distribution including: (1) subsp. europea with two botanical varieties europea (cultivated olive) and sy/vestris (wild olive), which is widely distributed throughout the Mediterranean Basin; (2) subsp. cuspidate distributed from SE Asia to SW China as well as the Arabian peninsula through East and South Africa; (3) subsp. laperrinei is restricted to the Sahara region; (4) subsp maroccana, which is restricted to Morocco; (5) subsp cerasiformis restricted to the island of Madeira; and, (6) subsp guanchica which is restricted to the Canary Islands. The olive tree is a prickly, long-living evergreen, reaching heights of $15 \mathrm{~m}$ and a branch spread of up to $9 \mathrm{~m}$. The olive tree's dense foliage is composed of elliptical-shaped leaves that are gray-green in color. Olive trees can have life spans of more than 500 years, with a few reaching 2,000 years (Doveri \& Baldoni 2007: 254). In advanced age, the olive tree trunk becomes hollow, acquiring its characteristic pattern of pronounced twists and protuberances on its bark and continues to add girth to its circumference.

\section{Olives: Origins and Development}

The hermaphroditic olive flowers are wind pollinated. Most trees are self-incompatible but a few are self-compatible (Doveri \& Baldoni 2007: 254). Olea europea L. is the only species that produces edible fruit (Manousis \& Moore 1988: 7). The olive is an oleaginous, one-seeded drupe with the fruit yielding up to $50 \%$ of its weight in valuable edible oil. Technically, the olive stone (endocarp) "is a fusiform, uni-integumented and sclerified endocarp, composed of two asymmetric valves [separated by a longitudinal suture line] protecting one seed" (Terral et al. 2004: 64), with the 
surface covered in longitudinally aligned furrows. The olive tree does not bear fruit for the first 10 or 12 years (Finley 1973: 31). The olive fruit takes 6-7 months to develop fully. The fruit grows slowly over the spring and summer months. A faster increase in size takes place in the autumn due to the water content. Restriction of fruit development can occur if exposed to prolonged droughts. The weight of an individual olive can vary between 1 and $15 \mathrm{~g}$. Oil deposition within the fruit starts at the beginning of the month of August, increases throughout the autumn, and then reaches its peak during November-January when the fruit turns completely black. Harvesting takes place in the autumn after the dramatic increase in size has occurred and the fruit starts to change color. For oil-producing olives, harvesting takes place when the olives are completely ripe, during the months of December or January, to permit the olives to obtain their maximum size and oil content. The commonest method of extraction of the oil from the pulp involves putting the fruit through mills of the edgerunner type (Manousis \& Moore 1988). Modern and traditional methods of olive oil production crush the entire olive fruit including the stone to increase oil production as the broken edges of the pit continue to grind the olive fruit, releasing more oil and facilitating the flow of the oil (Tyree \& Stefanoudaki 1996: 175). Subjected to intense climatic and anthropogenic manipulation, the olive tree is considered one of the most versatile and essential crops of the Mediterranean (Terral 2000: 127-8; Costantini \& Giorgi 2001: 246; Jashemski et al. 2002; Warnock 2007: 1). Olives were the primary source of edible fat in the Mediterranean used in cooking, soap manufacturing, ointment, perfume, fuel for illumination, and medicine (Finley 1973: 31; Meyer 1980: 405; Costantini \& Giorgi 2001: 246). During Roman times, there were about 20 different kinds of olive being cultivated in Italy, Spain, and North Africa; these differed in the shape; size; color of the olive fruits, from nearly white to green, violet, and deep purple; and, in the shape and size of the leaves, from small linearlaceolate to large ovate. Recent studies have shown olives contain antioxidants in abundance, represented by acteosides, hydroxytyrosol, tyrosol, and phenylpropionic acids (Doveri \& Baldoni 2007: 255).

\section{Major Domestication Traits}

It is believed that oleaster (Olea europaea Linn. var. sativa $\mathrm{DC}$ ) represents the progenitor stock from which the cultivated plant derives, which was endemic across the Mediterranean region and the Middle East (Doveri \& Baldoni 2007: 253). The domestication of olives has led to the selection of olive trees with larger fruit size and higher oil content under vegetative propagation 
from either cuttings or grafting to indigenous oleasters (Doveri \& Baldoni 2007: 253). The earliest signs for the domestication of olives are generally attributed to the areas bordering the east coast of the Mediterranean Sea during the Chalcolithic period from the fourth millennium BCE in Palestine (Zohary \& Hopf 1993: 141 in Zohary 1994: 62-63; Terral et al. 2004: 64). Olive domestication in the Near East is thought to have occurred in early Bronze Age, second half of the fifth millennium BCE, based upon the discovery of olive oil presses and the presence of pollen grains, olive stones, and wood remains (Doveri \& Baldoni 2007: 253). Olives have been discovered from the third millennium BC sites in Palestine and Syria and Bronze Age (3rd-2nd millennium BCE) sites in Cyprus, Greece, and northern Italy (Renfrew 1973). By the middle and late Bronze Age, olive cultivation and olive oil production seems to have been well established throughout the countries bordering the east shore of the Mediterranean

\section{Olives: Origins and Development}

Sea including Palestine and Syria to Greece (Zohary \& Spiegel-Roy 1975: 187). Recent molecular analysis based upon nuclear and cytoplasmic markers from both eastern and western Mediterranean populations found that these two populations are strongly differentiated from one another (Doveri \& Baldoni 2007: 255). There are now over 80 different kinds of olive trees grown in the Mediterranean Basin (Newberry 1937). It is not possible based upon palynological data to distinguish between wild and domesticated olives (Galili et al. 1997: 1141; Ciaraldi 2001: 172). Olives possess a high degree of variability in the size of the olive stone (endocarp) and it impossible to distinguish between the wild forms and those of cultivated varieties (Liphschitz et al. 1991: 441; Kislev 1996; Zohary \& Hopf 1988 cited in Galili et al. 1997: 1141). Recent genetic work has created genetic markers of $O$. europaea which would potentially allow for the germplasm identification of olives, even with the use of poorly preserved material from herbarium specimens or archaeobotanical material (Besnard et al. 2003). Due to their preferential preservation, olive stones (endocarps) are fairly ubiquitous and usually recovered from most Mediterranean archaeological sites (Finley 1973: 31; Terral et al. 2004: 63-64).

\section{Timing and Tracking Domestication}

Domesticated olives were brought to the New World in the fifteenth century by Europeans. This was the first time that the olive tree was cultivated outside the Mediterranean Basin. Today, the olive is grown commercially in Australia, South America (Argentina and Chile), and South Africa (Doveri \& Baldoni 2007: 253). Cultivated olives possess high variability. There 
are at least 1,275 known cultivars. Many local varieties and ecotypes have contributed to the richness of olive germplasm. Few cultivars are dispersed over widespread areas. The majority of olive cultivars are highly localized (Doveri \& Baldoni 2007: 254). Cultivars are mostly diploids with a few tetraploid plants reported (Doveri \& Baldoni 2007: 255). Some olive varieties are used for oil and some varieties for food as preserved olives (Feliks \& Gilboa 2007: 406). In processed olive fruits, sugar content varied among olive cultivars according to processing conditions (Marsilio et al. 2001: 485) (Fig. 1).

\section{Cross-References}

Agriculture: Definition and Overview

Archaeobotany of Early Agriculture:

Macrobotany

Date Palm: Origins and Development

Domestication Syndrome in Plants

Domestication: Definition and Overview

Figs: Origins and Development

Genetics of Early Plant Domestication: DNA

and aDNA

Grapes: Origins and Development

Plant Domestication and Cultivation in

Archaeology

Plant Processing Technologies in Archaeology

\section{References}

BESNARD, G., R. R. DE CASAS \& P. VARGAS. 2003. A set of primers for length and nucleotidesubstitution polymorphism in chloroplastic DNA of Olea europaea L. (Oleaceae). Molecular Ecology Notes 3: 651-653.

CIARALDI, M. R. A. 2001. Food and fodder, religion and medicine at Pompeii. Unpublished PhD dissertation, University of Bradford.

Olives: Origins and Development, Fig. 1 Whole carbonized Olea europea (olive) endocarp recovered from Insula VI.I, Pompeii, Italy (scale in centimeters) (Photo taken by author)

Olives: Origins and Development

COSTANTINI, L. \& J. GIORGI. 2001. Charred plant remains of the Archaic period from the Forum and Palatine. Journal of Roman Archaeology 14: 239-248. 
DOVERI, S. \& L. BALDONI. 2007. Olive, in C. Kole (ed.) Genome in mapping and molecular breeding in plants, Volume 4: fruits and nuts: 253-264. Berlin: SpringerVerlag.

FELIKS, J. \& S. GILBOA. 2007. Olives, in M. Berenbaum \& F. Skolnik (ed.) Encyclopaedia Judaica, Volume 15: 406-407, 2nd edn. Detroit: Macmillan Reference USA,

FINLEY, M. I. 1973. The ancient economy. London: Chatto \& Windus.

GALILI, E., D. J. STANLEY, J. SHARVIT, \& M. WEINSTEINEVRON. 1997. Evidence for earliest olive-oil production in submerged settlements off the Carmel coast, Israel. Journal of Archaeological Science 24(12): 1141-1150.

JASHEMSKI, W. F., F. G. MEYER\& M. RICCIARDI. 2002. Plants: evidence from wall paintings, mosaics, sculpture, plant remains, graffiti, inscriptions, and ancient authors, catalogue of plants, in The natural history of Pompeii: 80-180. Cambridge: Cambridge University Press.

KISLEV, M. E. 1996. The domestication of the olive tree, in D. Eitam \& M. Heltzer (ed.) Olive oil in antiquity, Israel and neighbouring countries from the Neolithic to the Early Arab Period (History of the Ancient Near East Studies 7): 3-6. Padova: Sargon.

LIPHSCHITZ, N., R. GOPHNA, M. HARTMAN \& G. BIGER. 1991. The beginning of olive (Olea europea) cultivation in the Old World: a reassessment. Journal of Archaeological Science 18: 441-453.

MANOUSIS, T. \& N. F. MOORE. 1988. The olive tree. Biologist 35(1): 7-13.

MARSILIO, V., C. CAMPESTRE \& B. LANZA. 2001. Phenolic compounds change during California-style ripe olive processing. Food Chemistry 72(4): 485-490.

MEYER, F. G. 1980. Carbonized food plants of Pompeii, Herculaneum, and the Villa at Torre Annunziata. Economic Botany 34(4): 401-437.

NEWBERRY, P. E. 1937. On some African species of the genus olea and the original home of the cultivated olive-tree. Proceedings of the Linnean Society of London 150: 3-16.

RENFREW, J. M. 1973. Palaeoethnobotany: the prehistory of food plants of the Near East and Europe. London: Methuen.

TERRAL, J.-F. 2000. Exploitation and management of the olive tree during prehistoric times in Mediterranean France and Spain. Journal of Archaeological Science 27(2): 127-133.

TERRAL, J.-F., N. ALONSON, B. I. CAPDEVILLA, N. CHATTI, L. FABRE, G. FIORENTINO, P. MARINVAL, G. PEREZ JORDA, B. PRADAT, B. ROVIRA \& P. ALIBERT. 2004. Historical biogeography of olive domestication (Olea europaea L.) as revealed by geometrical morphometry applied to biological and archaeological material. Journal of Biogeography 31: 63-77.

TYREE, E. L. \& E. STEFANOUDAKI. 1996. The olive pit and Roman oil making. The Biblical Archaeologist 59(3): 171-178.

WARNOCK, P. 2007. Identification of ancient olive oil processing methods based on olive remains (BAR International series 1635). Oxford: Archaeopress.

ZOHARY, D. 1994. The wild genetic resources of the cultivated olive. Acta Horticulturae 356: 62-65. 
ZOHARY, D. \& M. HOPF. 1993. Domestication of plants in the Old World: the origin and spread of cultivated plants in West Asia, Europe and the Nile Valley, 3rd edn. Oxford: Clarendon Press \& Oxford University Press.

ZOHARY, D. \& P. SPIEGEL-ROY. 1975. Beginnings of fruit growing in the Old World. Science 187(4174): 319-327.

Further Reading

ZOHARY, D. \& M. HOPF. 2001. Domestication of plants in the Old World: the origin and spread of cultivated plants in West Asia, Europe and the Nile Valley, 3rd edn. Oxford: Oxford University Press. 